\title{
Domestic Violence in a COVID-19 Context: Exploring Emerging Issues through a Systematic Analysis of the Literature
}

\author{
Maria Pentaraki' ${ }^{1}$ Janet Speake ${ }^{1,2}$ \\ ${ }^{1}$ School of Social Sciences, Education and Social Work, Queen's University, Belfast, UK \\ ${ }^{2}$ Liverpool Hope University, Liverpool, UK \\ Email: m.pentaraki@qub.ac.uk, j.speake@qub.ac.uk
}

How to cite this paper: Pentaraki, M., \& Speake, J. (2020). Domestic Violence in a COVID-19 Context: Exploring Emerging Issues through a Systematic Analysis of the Literature. Open Journal of Social Sciences, $8,193-211$.

https://doi.org/10.4236/jss.2020.810013

Received: September 5, 2020

Accepted: October 24, 2020

Published: October 27, 2020

Copyright $\odot 2020$ by author(s) and Scientific Research Publishing Inc. This work is licensed under the Creative Commons Attribution International License (CC BY 4.0).

http://creativecommons.org/licenses/by/4.0/

\begin{abstract}
Extreme events, such as pandemics lead to a rise of domestic violence (DV) and create additional challenges for practice. The social work profession as well as many other professions works with women who have experienced DV and so it is important to be up-to-date with the emerging issues brought about by the Coronavirus (COVID-19) pandemic. The aim of this article is to identify emerging issues related to DV within the context of COVID-19. The article presents the results of a systematic literature search and analysis of DV within the COVID-19 pandemic in 2020. A systematic search of 10 data bases was conducted. All articles in peer reviewed journals discussing DV in the context of COVID-19 were included. For the articles to be included they had to be written in the English language and to be included in peer reviewed journals between 1 January 2020 to 9 May 2020. Of the 413 articles initially recorded, 12 articles were identified which focused on DV. The analysis of the 12 identified articles offers some useful insights. It suggests that lockdown measures imposed by governments intensify perpetrators' power over survivors' lives, hence reinforcing gender inequality. Furthermore, it indicates that online provision of support might not be the most effective response in cases of DV and identifies appropriate emergency warning systems. Additionally, the risk of scapegoating COVID-19 for DV is identified. These insights are briefly discussed in relation to practice and policy responses.
\end{abstract}

\section{Keywords}

COVID-19, Coronavirus, Domestic Violence, Gender Based Violence, Coercive Control, Technology 


\section{Introduction}

Social workers as well as other professionals such as doctors, nurses, and psychologists work with women who have experienced Domestic Violence (DV)/Intimate Partner Violence (IPV) (Allen, 2014; Danis, 2003; Fogel \& Woods, 2008; Holt et al., 2017; Nicolson, 2019; Williamson, 2000). Thus, it is important for these professionals to be up-to-date with the emerging issues brought about by the COVID-19 pandemic in 2020. Traditionally, one of the foci of social work has been the interaction between people and the environment. Changes in the environment (Pentaraki, 2013b), such as those related to the pandemic highlight issues about which the social work profession should be informed. Thus, this paper aims to identify and highlight emerging issues in the area of DV linked to COVID-19, which can inform the social work profession as well as other relevant professions. It reports on a systematic search and analysis of literature in peer reviewed journals on DV and the COVID-19 pandemic. Before reporting on this process, the underlying context for this work is introduced.

Women across the world are subjected to physical, psychological, sexual, economic and other forms of violence and abuse by their (ex)partners (Council of Europe, 2011). This form of violence has been referred to as domestic violence (DV) or intimate partner violence (IPV). DV/IPV is a widespread social and public health problem (World Health Organization (WHO), 2013). IPV is a gendered phenomenon as it primarily affects women (World Health Organization (WHO), 2013) and to a lesser degree, men. This paper reflects this by utilizing a gender-based language which recognizes that the majority of survivors in heterosexual relationships are women. However, the authors acknowledge that both women and men in same sex (Pentaraki, 2017) and opposite sex relationships may be survivors. Worldwide, $18 \%$ of ever-partnered women aged 15 to 49 years experienced sexual and/or physical violence by an intimate partner in the previous 12 months (United Nations Women (UN Women), 2020b). Once lifetime statistics are taken into consideration, this number rises to approximately one in three women experiencing DV during their lifetime (United Nations (UN), 2015; World Health Organization (WHO), 2013). Moreover, previous research has indicated that within the context of extreme events such as war, conflicts, disaster, and pandemic emergencies, there is an increase in the prevalence of IPV (Ali et al., 2011; Bermudez et al., 2019; Castañeda Camey et al., 2020; Garcia-Moreno et al., 2006; Gearhart et al., 2018; Kumar, 2020; Parkinson \& Zara, 2013; Peterman et al., 2020; Schumacher et al., 2010; United Nations (UN), 2015). One of the latest extreme events being faced globally is the COVID-19 health emergency which has crossed international boundaries and constitutes a pandemic and has infected millions of people across the world. Up to 23 May 2020 a total of 5,103,006 cases of COVID-19 and 333,401 deaths had been reported (World Health Organization (WHO), 2020a). Movement restrictions necessary to flatten the exponential growth curve of the pandemic, have forced people to spend more time at home during government imposed quaran- 
tine/lockdown measures. Home, however, is a very dangerous place for women survivors of DV (Diemer et al., 2017) and the enforced measures of distancing force women survivors to spend more time at home with their abusers. Thus, as expected on the basis of research relating to DV during other extreme events, the COVID-19 pandemic context brought increased reported cases of DV (Graham-Harrison et al., 2020; Kumar, 2020). In China, it has been reported that occurrences of DV have nearly doubled in the city of Jingzhou, southern Hubei province (Zhang, 2020). In Singapore, Cyprus, and the UK, helplines have rec-

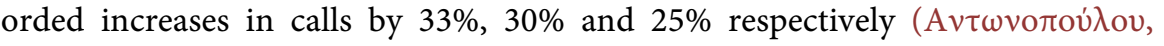
2020; Hingorani, 2020; Refuge, 2020). According to data from the "180 Hotline" provided by the Ministry for Women, Family, and Human Rights in Brazil there was a 17\% increase in DV related calls during March 2020, the month that social distancing was recommended (Marques et al., 2020).

In many countries, there have been reports on the increase of domestic homicides/femicides (Bradbury-Jones \& Isham, 2020; Ingala Smith, 2020). In Greece, the UK, France, and South Africa for example, increases in DV have been re-

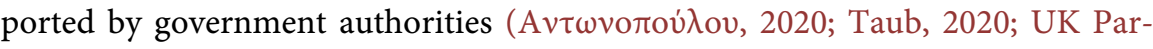
liament, 2020; Weiner, 2020). The United Nations Population Fund (United Nations Population Fund (UNFPA), 2020) projected that for every three months that the lockdown continued, an additional 15 million cases of IPV were expected across all 193 United Nations member states.

Only when the increase of DV was highlighted by concerned individuals, groups, and the media did governments attempt to provide relevant measures to support survivors of DV (Taub, 2020). Initially there was an absence of such provision during government imposed lockdown and quarantine measures. This seems to be related to a predominance of virologists, epidemiologists and politicians in COVID-19 government decision making bodies (Rajan et al., 2020). Civil society, community groups, child development specialists, social workers, and human rights lawyers as well as other professionals whose expertise is relevant to address human needs holistically were not being engaged in the primary discussion stages (Rajan et al., 2020). This accounts for the absence of information related to the challenges of isolation measures faced by various groups in society such as the survivors of domestic violence (Rajan et al., 2020). Having provided a background context, the paper now presents the systematic search and analysis of the literature.

\section{Method}

A systematic search of the literature was conducted to identify articles reporting on COVID-19 and domestic violence published in peer reviewed journals from 1 January 2020 to 9 May 2020. This systematic search was conducted in order to enhance our understanding of emerging issues related to DV in the changing environment of the pandemic. Systematic search guidelines based on the Preferred Reporting Items for Systematic Reviews and Me- 
ta-Analyses criteria (Moher et al., 2009) were rigorously followed in order to eliminate search bias (see Figure 1). The paper reports on this systematic literature search and its analysis, even though no original research articles were identified due to the recent nature of the pandemic. However, as the social work profession acknowledges that in addition to research knowledge there are a wide range of sources of knowledge (Nevo \& Slonim-Nevo, 2011; Pawson et al., 2003). This systematic literature search and analysis builds on this understanding and as such aimed to locate every relevant article in peer reviewed academic journals.

The literature search focused on articles which discussed DV within the context of COVID-19. An article was included if it met the following three criteria namely that it: 1 ) reported on COVID-19 and DV; 2) was published in a peer reviewed journal between 1 January 2020 and 9 May 2020; 3) was written in the English Language.

The data bases were searched with the following key words (COVID-19 OR coronavirus OR SARS-CoV-2) AND (domestic violence OR domestic abuse OR intimate partner violence OR domestic violence). The search yielded 413 records in 10 data bases. The data bases were Social Policy and Practice, APA PsycINFO, EMBASE and MEDLINE (accessed via the All Ovid data base platform $(n=9)$; CINAHL Plus $(n=6)$, PUBMED $(n=8)$, Science Direct $(n=55)$. Scopus $(n=1)$ Web of Science $(n=1)$, and Google Scholar $(n=333)$.

Figure 1 presents a flow chart of the literature selection process. It shows that

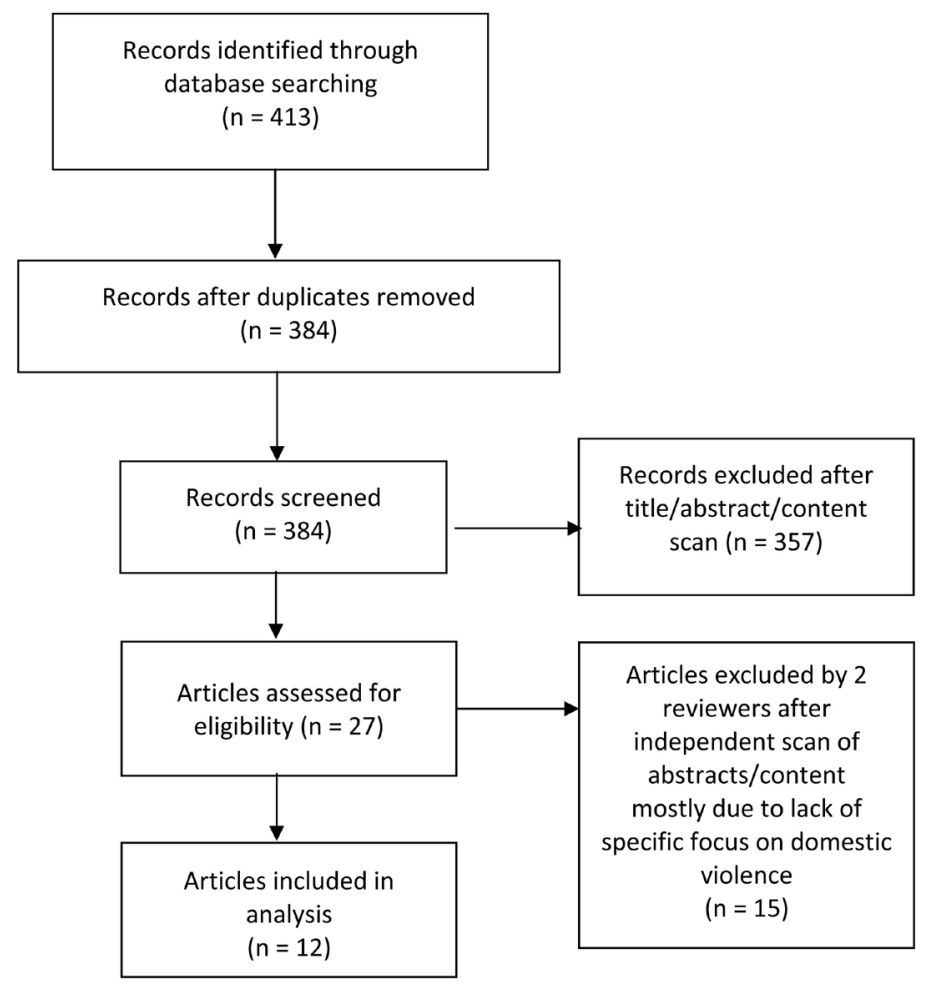

Figure 1. Flow chart of article selection. 
together these data bases searches revealed 413 records in total. Of these, 29 were removed due to duplication, leaving a total of 384 records to be screened by two reviewers. First the titles and abstracts of these records were screened by a reviewer to identify which articles addressed domestic violence and COVID-19. During this first stage of title and abstract scanning 357 articles were excluded and 27 articles were retained. The principal reason for the exclusion of the articles at this stage was that they focused on either DV or COVID-19 but not both together. In the second stage of article selection, a more detailed assessment was conducted by two reviewers. The two reviewers independently screened the abstracts and/or content of the retained 27 articles to determine eligibility for further analysis. When the reviewers' assessments were compared both reviewers had identified the same 12 articles to be retained for further examination. The reasons for the exclusion of the other 15 articles were mostly due to lack of specific focus on domestic violence. At the third stage the reviewers engaged in an in-depth review of the full text of the 12 identified articles, the results of which are presented next.

\section{Results}

Twelve articles were identified for analysis from the systematic literature search as outlined in the previous section (see Table 1). This scholarly work comprised articles $(n=5)$, commentaries $(n=5)$, editorial piece $(n=1)$ and notes from the field $(n=1)$. No research studies were identified. This is due to the recent nature of the pandemic which has precluded the publication of research studies to date. The origin and the content of the identified articles reflect the global nature of DV and the COVID-19 pandemic. The work covers examples from both the global north $(\mathrm{n}=9)$ and the global south $(n=3)$. The articles were from a variety of disciplines, including mental health, nursing and medicine. DV associated with COVID-19 is a concern in many disciplines which reflects a multidisciplinary recognition of the serious nature of DV. All of the articles but one (Ragavan et al., 2020), refer to general issues of DV in adult intimate relationships. Ragavan et al. (2020) address violence in adolescent relationships. It is important to note that none of the identified articles were in peer reviewed social work journals. This absence in the social work literature highlights the need for this present study and for further research.

Due to the nature of the scholarly work located, it was decided to conduct a narrative review summarizing the salient themes of the various publication types. Four main themes were identified. These were: 1) lockdown measures imposed by governments during quarantine reinforce perpetrators' coercive control tactics; 2) online support measures may not be appropriate to survivors of DV; 3) specific interventions and strategies related to addressing DV within the context of COVID-19; 4) contesting understandings of DV within the COVID 19 context and the risk of scapegoating COVID-19 as the cause of DV. 
Table 1. Summary of reviewed articles on COVID-19 and domestic violence.

\begin{tabular}{|c|c|c|c|c|c|}
\hline$\neq$ & $\begin{array}{c}\text { Author }{ }^{1} \text { and title } \\
\text { ('arranged alphabetically) }\end{array}$ & Location & $\begin{array}{l}\text { Article } \\
\text { type }\end{array}$ & $\begin{array}{l}\text { Subject } \\
\text { area }\end{array}$ & Key messages \\
\hline 1 & $\begin{array}{l}\text { Boserup B, McKenney M and } \\
\text { Elkbuli A (2020) } \\
\text { Alarming trends in US domestic } \\
\text { violence during the COVID-19 pandemic }\end{array}$ & $\begin{array}{l}\text { USA study. } \\
\text { USA based } \\
\text { authors }\end{array}$ & $\begin{array}{l}\text { Short } \\
\text { article }\end{array}$ & $\begin{array}{l}\text { Emergency } \\
\text { medicine }\end{array}$ & $\begin{array}{l}\text { Lack of established support. } \\
\text { Important role of health care staff. } \\
\text { Need for screening tools. }\end{array}$ \\
\hline 2 & $\begin{array}{l}\text { Bradbury-Jones C. and Isham L. (2020) } \\
\text { The pandemic paradox: } \\
\text { the consequences of COVID-19 } \\
\text { on domestic violence }\end{array}$ & $\begin{array}{l}\text { General study. } \\
\text { UK based } \\
\text { authors }\end{array}$ & Editorial & $\begin{array}{l}\text { Clinical } \\
\text { nursing }\end{array}$ & $\begin{array}{l}\text { Survivors may not have access to } \\
\text { online technologies/phone as they } \\
\text { may be unaffordable and because } \\
\text { of the control tactics of perpetrators. } \\
\text { Lockdown measures give more power } \\
\text { for perpetrators to act without } \\
\text { scrutiny and consequence. }\end{array}$ \\
\hline 3 & $\begin{array}{l}\text { Bradley NL, DiPasquale } \\
\text { AM, Dillabough K and Schneider PS (2020) } \\
\text { Health care practitioners' responsibility to } \\
\text { address intimate partner violence related } \\
\text { to the COVID-19 pandemic }\end{array}$ & $\begin{array}{l}\text { General study. } \\
\text { Canada } \\
\text { based authors }\end{array}$ & Commentary & $\begin{array}{l}\text { Health } \\
\text { care } \\
\text { workers }\end{array}$ & $\begin{array}{l}\text { Necessity for safe emergency warning } \\
\text { systems to be used by survivors such } \\
\text { as safe words and signal for help. }\end{array}$ \\
\hline 4 & $\begin{array}{l}\text { Campbell AM (2020) An increasing risk } \\
\text { of family violence during the Covid-19 } \\
\text { pandemic: Strengthening } \\
\text { community collaborations to save lives }\end{array}$ & $\begin{array}{l}\text { USA study. } \\
\text { USA } \\
\text { Based author }\end{array}$ & Commentary & $\begin{array}{l}\text { Forensic } \\
\text { science }\end{array}$ & $\begin{array}{l}\text { Perpetrator imposed restrictions and } \\
\text { continued surveillance using technological } \\
\text { means limit the ability of survivors to reach } \\
\text { out for help electronically. } \\
\text { Opportunities for abuse expanded by } \\
\text { perpetrators' use of COVID-19 as a weapon } \\
\text { against survivors, includes forbidding } \\
\text { handwashing in an attempt to increase the } \\
\text { survivors' fear of contracting the virus and } \\
\text { threatening to prohibit medical treatment } \\
\text { if the survivor contracts the virus. } \\
\text { Exploring the impact of natural disaster } \\
\text { literature may provide important insights. } \\
\text { Need for community collaborations. }\end{array}$ \\
\hline 5 & $\begin{array}{l}\text { Dyer H, Stelly D and Watson GL (2020) } \\
\text { Intimate partner violence: } \\
\text { Using standardized } \\
\text { patients to Improve trauma-informed } \\
\text { care in the era of the Covid-19 pandemic }\end{array}$ & $\begin{array}{l}\text { Barbados/general } \\
\text { study. } \\
\text { Barbados based } \\
\text { authors }\end{array}$ & $\begin{array}{l}\text { Opinion } \\
\text { piece }\end{array}$ & Medicine & $\begin{array}{l}\text { Importance for the medical training } \\
\text { curriculum to include } \\
\text { preparing students to be aware of their } \\
\text { own traumatic experiences } \\
\text { during the pandemic. }\end{array}$ \\
\hline 6 & $\begin{array}{l}\text { John N, Casey S, Carino and } \\
\text { McGovern T (2020) Lessons } \\
\text { Never Learned: Crisis and gender-based } \\
\text { violence }\end{array}$ & $\begin{array}{l}\text { USA study.USA } \\
\text { based authors }\end{array}$ & $\begin{array}{l}\text { Article-special } \\
\text { issue }\end{array}$ & $\begin{array}{l}\text { General } \\
\text { IPV }\end{array}$ & $\begin{array}{l}\text { COVID-19 exposes existing } \\
\text { socio-economic inequalities, } \\
\text { such as gender based violence. } \\
\text { Measures such as quarantines have } \\
\text { increased women's exposure to violence } \\
\text { as confinement in physical spaces along } \\
\text { with economic and health shocks have } \\
\text { increased household stress levels. } \\
\text { Support services strained. } \\
\text { Take into account lessons learned from } \\
\text { prior emergencies to avoid ongoing } \\
\text { mistakes. Urges the inclusion of women in } \\
\text { all COVID-19 decision-making processes. } \\
\text { The UN agencies UN Women and UNFPA } \\
\text { have developed guidelines on } \\
\text { gender-based violence and COVID-19 } \\
\text { for governments to use. }\end{array}$ \\
\hline
\end{tabular}



Ndwandwa ES, Wilson P, King A and

7 Sikkema KJ (2020) COVID-19: Increased Risk to the Mental Health and Safety of Women Living with HIV in South Africa
Joska JA, Andersen L, Rabie S, Marais A,
South Africa study. South Africa and USA based authors

Notes from the field
Aids and

Behaviour

Mental

Health and

HIV and

COVID-19
Women with HIV have a high prevalence rate of IPV.

Movement restrictions imposed within the context of COVID-19 may rekindle trauma related to restrictions applied to specific communities during Apartheid in South Africa.

Telepsychiatry is not an option for people in poverty.

Constant around-the-clock contact, especially in low-income families living in housing with few rooms and overcrowding, decreases the possibilities for survivors to ask for help. Longer time in contact with the aggressor leads to reduction of the support network

Brazil study. Brazil Literature Public based authors review health (2020) Violence against women, child 8 and adolescents during the COVID-19. pandemic: Overview, contributing factors, and mitigating measures.

Mazza M, Marano G, Lai C, JaniriL and 9. Sani G (2020) Danger in danger: Interpersonal violence during COVID-19 quarantine

Ragavan MI, Culyba AJ, Muhammad FL and Miller E (2020) Supporting

10 adolescents and young adults exposed to or experiencing violence during the COVID-19 pandemic
Italy study. Italy based authors

USA study. Literature USA based authors based article Short
communication Psychiatry

\section{(both informal and formal).}

Women's vulnerability is increased for the following reasons: individual (perpetrator's stress, increased alcohol consumption, loss of source of income), relational (more time with perpetrator, less access to support network) and community (less access to services and institutions) level factors.

Perpetrators' aggression rises due to the feelings of frustration and agitation. Individual risk factors discussed with an emphasis placed on mental health disorders, stress and substance abuse. Relation of domestic violence to psychiatric disorders.

Adolescents' increased reliance on technology creates opportunities for abuse, where abusive partners control, stalk, or discredit their partners through Adolescent texts, social media, or mobile applications. health Not all adolescents have access to stable sources of internet, data access, and phone and computer equipment. Mental health care professionals need to advocate access to free or low-cost technology.

Depletion of existing support networks through lockdown measures. Provision of emergency warning systems in pharmacies and grocery stores in France so that people can indicate

Usher K, Bhullar N, Durkin J, Gyamfi N and Jackson D (2020) Family violence and 11 COVID-19: Increased vulnerability and reduced options for support
Australia study. Australia based authors
Literature General based article IPV that they are in danger and need support. COVID-19 is used as a coercive control mechanism. Perpetrators increase their control through the use of containment, fear, and threat of contagion. Examples from charities in Australia include the use misinformation by perpetrators related to the extent of quarantine measures. 


\section{Continued}

Van Gelder N, Peterman A, Potts A, O'Donnell M, Thompson K, Shah N and

12 Oertelt-Prigone S (2020) COVID-19: Reducing the risk of infection might increase the risk of intimat partner violence
IPV can be triggered by a number of factors, such as economic and psychological stress related to the COVID-19 context as well as potential General study. $\quad$ increases in negative coping mechanisms Europe and USA Commentary General (e.g. excessive alcohol consumption). based authors There is an overlap of strategies employed in abusive relationships with the measures imposed during quarantine, such as the enforced of isolation from support networks.

\subsection{Theme 1: Lockdown Measures Imposed by Governments during Quarantine Reinforce Perpetrator's Coercive Control Tactics}

Six articles discuss that lockdown imposed measures by the government facilitate and reinforce perpetrators' coercive control, which is one of the main features of domestic abuse (Bradbury-Jones \& Isham, 2020; Boserup et al., 2020; Campbell, 2020; Marques et al., 2020; Usher et al., 2020; Van Gelder et al., 2020).

Van Gelder et al. (2020) suggest that the conditions of isolation/physical distancing imposed by the governments overlap with the coercive control strategies used by perpetrators to control their partners. Isolation is already a feature in the lives of survivors which is further exacerbated by quarantine and lockdown measures. Characteristic of this double isolation is the isolation from formal or informal support networks, as a result of the continuous surveillance and control of daily activities (Boserup et al., 2020; Marques et al., 2020; Usher et al., 2020; Van Gelder et al., 2020). Furthermore, Bradbury-Jones \& Isham (2020) suggest that the power of the perpetrators to act without scrutiny and consequence is a consequence of the lockdown measures.

Additionally, two articles (Campbell, 2020; Usher et al., 2020) mention that COVID-19 is used as a weapon. Specific examples provided are perpetrators threatening to block access to medical treatment in case the survivor contracts the virus and forbidding handwashing to exacerbate the survivor's fear of contracting it. Also, Usher et al. (2020) refer to reports of misinformation related to the extent of quarantine measures given to survivors by perpetrators in order to exert further control.

\subsection{Theme 2: Online Support Measures May Not Be Appropriate to Survivors of DV}

Five articles discuss that online support measures may not be appropriate to survivors of DV during the lockdown period. A number of relevant issues were covered. The first issue relates to the control tactics of the perpetrator (Bradbury-Jones \& Isham, 2020; Campbell, 2020; Ragavan et al., 2020) and the second issue relates to unaffordability (Bradbury-Jones \& Isham, 2020; Joska et al., 2020; 
Ragavan et al., 2020). The control tactics of the perpetrator are discussed in terms of perpetrator imposed restrictions, perpetrator surveillance of social media, internet, and cell phones, all of which limit out the ability of survivors to obtain help through online and digital means (Campbell, 2020). Another insight made is that confinement in smaller spaces raise additional difficulties for survivors to ask for help safely and confidentially (Marques et al., 2020). Smaller homes make it more difficult to find a space from which to seek help and harder to escape round the clock contact and surveillance by the perpetrator.

Bradbury-Jones \& Isham (2020) allude to the fact that survivors' access may be blocked. This insight raises questions in terms of who controls access to available resources within the home. Whereas, Ragavan et al. (2020) remind us that even young people in an intimate relationship who are not confined with them in the same house face issues of surveillance and abuse through online means.

Joska et al. (2020) writing from South Africa discusses the need of a contextual approach due to extreme rates of poverty experienced by some groups of women. This point is reiterated by Ragavan et al. (2020) talking about young adolescents in USA who might not have access to stable sources of internet through which to engage in online support services such as telehealth. Within this context they argue for free or low-cost technology.

\subsection{Theme 3: Specific Interventions and Strategies Related to Addressing DV within the Context of COVID-19}

Three articles discuss specific interventions (Bradley et al., 2020; John et al., 2020; Usher et al., 2020) which have emerged to address DV within the context of COVID-19. The main theme of the discussed approaches is the ability to ask for help without leaving a digital trace. Bradley et al. (2020) refer to the "The Signal for Help" emergency warning system of the Canadian Women's Foundation which aims to provide the ability to women survivors to safely ask for help without leaving a digital trace during telemedicine. It is a hand signal made by survivors of DV which acts as a silent request for assistance from health care practitioners. When health care practitioners see this signal, they are made aware that assistance is required. In addition to "The Signal for Help" system, Usher et al. (2020) discuss "Safe Word" emergency warning systems adopted in France by pharmacies and grocery stores by which survivors can indicate they need support through the use of safe words.

\subsection{Theme 4: Contesting Understandings of DV within the COVID-19 Context and the Risk of Scapegoating COVID-19 as the Cause of DV}

The literature analysis reflected a contested understanding of DV. This ranged from scapegoating COVID-19 as a cause of DV to approaching COVID-19 as providing a context which exposed existing gender inequalities such as DV. 
Mazza et al. (2020) discuss that DV aggression arises due to the feelings of frustration and agitation arising from the COVID-19 context. This approach risks scapegoating COVID-19 as the cause of DV. However, other identified publications (John et al., 2020; Van Gelder et al., 2020) recognize that these are just the trigger. Moreover, John et al. (2020) state that COVID-19 exposes existing inequalities, such as gender based violence, a dimension of which is DV.

In summary, overall the results suggest that lockdown measures imposed by governments intensify perpetrators' power over survivors' lives, hence reinforcing gender inequality. They indicate that online provision of support might not be the most effective response in cases of DV and identify appropriate emergency warning systems. Furthermore, the risk of scapegoating COVID-19 for DV is also identified. In addition to these insights a number of evidence gaps were revealed. These were the absence of empirical evidence on COVID-19 and DV/IPV, lack of evaluation of best practices to address DV/IPV, lack of articles related to social work, and a scarcity of literature on issues related to LGBT, migrant, asylum seekers, refugees, and other minority survivors. All of these offer foci for future research.

\section{Discussion}

The aim of this systematic search of the literature was to identify emerging issues related to DV within the context of the COVID-19 pandemic. The review of the available literature in peer reviewed journals provides some useful insights to inform social work practice and other relevant professions practice and research.

One of these insights is that the provision of online services is not an appropriate medium for survivors of DV during the pandemic for two basic reasons. First is that some women may not be able to afford technological means of communication and broadband (Joska et al., 2020; Ragavan et al., 2020). This leads to a necessity for the social work profession to lobby to promote greater digital equality in order to address this digital divide and leave no one behind in an era of rapid advances in online technologies. Secondly and importantly, is that the online provision of support entails risks for DV survivors. Survivors who are being enclosed with a perpetrator due to lockdown measures cannot safely communicate with support services. It has been identified in pre COVID-19 research that perpetrators may monitor the technological means by which survivors may communicate (Pentaraki \& Speake, under review; Woodlock et al., 2020)1. The opportunities to monitor the communication channels have been increased during the COVID-19 context due to the greater time that survivors spend with the perpetrator. Social workers, as well as the other professionals working in the area of DV, need to assume that perpetrators see, hear and monitor every form of the survivors' communications (World Health Or-

${ }^{1}$ For a list of safety measures that can be considered to protect the survivors from technologically facilitated abuse see for example (National Network to End Domestic Violence (NNEDV), 2019; Pentaraki, 2019a; Pentaraki \& Speake, under review). 
ganization (WHO), 2020b) which increases the danger to them. Thus, emphasis needs to be placed in providing very discreet ways of activating the process of help-seeking, such as "The Signal for Help" hand gesture as is carried out in Canada, which enable the survivor to activate the help-seeking process without leaving a digital trace. Relevant toolkits for "The Signal for Help" and strategies on its utilization are provided in the website of the Canadian Women's Foundation (2020).

Likewise, pharmacies and supermarkets provide important alternative community avenues of activating the process of help-seeking within the wider community. In France survivors can activate the process of help-seeking through the use of safety words (Usher et al., 2020). This finding highlights the importance of community development work (Pentaraki, 2009) and the need to mobilize every sector in the community to play a role in addressing DV. In addition to France this approach has also been implemented in Spain, Germany, Italy, Norway and Argentina where, similarly, survivors can use a safe word such as "Mask 19" in pharmacies to indicate they need help (Higgins, 2020; Vieira et al., 2020). This seems to be an approach which should be maintained and even expanded after the end of lockdowns linked to the COVID-19 pandemic. However, this might be easier in some countries than others depending on each community's attitudes towards DV and available structures which can respond. Additional proposals which enhance the safety of survivors are provided by the World Health Organization (WHO) (2020b) and United Nations Women (UN Women) (2020a) including one from Cumbria, UK where postal workers and delivery drivers have been enlisted by the police to look out for signs of abuse (United Nations Women (UN Women), 2020a). Also in the UK, a "silent solution" is provided whereby survivors calling the emergency number (999) instead of talking they can respond by tapping into the handset or coughing and if prompted can press 55 on the phone. This will indicate that there is an emergency. For additional suggested safety measures within the COVID-19 context see Women's Aid (2020).

Another insight is that survivors of abuse face double risks during pandemics, the risk of the pandemic and the increased risk of the violence. The literature highlighted that the coercive control tactics of perpetrators are intensified by government imposed quarantine and lockdown measures. At the core of DV/IPV has been a pattern of coercive control (Pence \& Paymar, 1993; Stark, 2007). Perpetrators seek to exercise control over the survivors and one of the major tactics used is the isolation of the survivors from support networks (Pence \& Paymar, 1993; Stark, 2007). Lockdown scenarios reinforce this isolation through the enforced continuous coexistence between perpetrator and survivor. Isolation reinforces the power of the perpetrator. The perpetrator spends more time with the survivor and uses the COVID-19 context as an opportunity to further intimidate them in various ways, such as telling them what they can or cannot do (wash or do not wash their hands etc.) and spreading false information regarding the quarantine measures. Opportunities for abuse increase and 
the lockdown measures further isolate the survivor from support. Thus, from the start government decision making bodies and emergency response authorities should exclude survivors of IPV from restricted movement during periods of lockdown. Social workers, due to their expertise in working with DV survivors, should highlight the need for their inclusion in government decision making emergency response teams in order to account not only for the need of DV survivors but also for the needs of others such as abused children, who face heightened risk during pandemics. This will help to overcome the "tyranny of the urgent" (Smith, 2019: p. 355) and provide a more inclusive way of addressing people's needs from the onset of the lockdown measures (John et al., 2020; Rajan et al., 2020).

A further issue identified is the risk of scapegoating COVID-19 for causing DV (Mazza et al., 2020). It is important to remember that COVID-19 and its related stressful conditions do not transform people who have no inclination to control their partner into perpetrators (Dalton, 2020). Control is the primary feature of the majority of cases of DV (Allen, 2014; Johnson, 2006; Johnson et al., 2014; Pence \& Paymar, 1993; Stark, 2007; True, 2012). To assume that the predominant cause of DV during the pandemic are the conditions created by COVID-19 can lead to ineffective responses. Stress or substance abuse can be the trigger for violence, however it should only be regarded as the cause of violence when the perpetrators of DV are also violent towards other people with whom they come into contact (Pence \& Paymar, 1993). In most cases COVID-19 conditions are the trigger rather than the cause (Van Gelder et al., 2020). Such issues can be explored in follow-up research in post COVID-19 conditions.

The understanding of COVID-19 conditions as a cause rather than a trigger of violence relocates the responsibility away from the perpetrators to factors that are beyond their control, such as stress connected to COVID-19 and the associated measures of quarantine and lockdown etc. This understanding can lead to a reductionist approach to DV as it ignores its social causes (Allen, 2014; Johnson, 2006; Johnson et al., 2014; Pence \& Paymar, 1993; Stark, 2007; True, 2012). However, John et al. (2020) drawing from previous scholarly work on extreme events, highlight the social causes of DV in their assertion that COVID-19 exposes existing inequalities, such as gender inequalities and gender based violence, of which a dimension is DV.

Scholarly work on extreme events indicate that these are inherently social processes (Blaikie et al., 1994) which impact individuals differently based on class, gender, ethnicity, age and disability (Ariyabandu \& Wickramasinghe, 2003; Blaikie et al., 1994; Fisher, 2010; Pentaraki, 2013b) thereby reinforcing existing inequalities. This is indicated in the way that survivors of DV are impacted by extreme events. Gender inequality, which underlines the majority of DV cases (Jakobsen, 2014; Stark, 2007; True, 2012) is reinforced within the context of the COVID-19 pandemic (John et al., 2020). Women are intimidated, told not to wash their hands, threatened with medical neglect, and given false information 
regarding lockdown measures etc. These examples reflect the power and control tactics of the perpetrator, which in turn can reinforce gender inequality. Gender inequality is reinforced if governments impose measures from the outset of pandemic, which do not enable survivors to break lockdown to seek help. Survivors are thus double-isolated as a result of perpetrators and governments' actions. Furthermore, living in remote rural areas can add an additional layer of isolation (triple-isolation). However, women's lives within COVID-19 are not only negatively impacted by DV. Their lives have become more burdened with additional caring responsibilities, job insecurity and reduced earnings as evidenced from real-time surveys (Adams-Prassl et al., 2020). Additional challenges are faced by survivors of DV due to "race", ethnicity, sexual orientation, disability and age inequalities (Pentaraki, 2017). These are issues which will need to be considered through an intersectional approach (Slakoff et al., 2020) in order to respond appropriately to DV and furthermore necessitate well-funded services which in many countries have been undermined by austerity (O'Hara, 2015; Pentaraki, 2013a). There is a concern that COVID-19 government spending will be used as a pretext to impose further austerity cuts and thus further undermine existing social services, such as those related to addressing domestic violence, in the same way that the financial crisis was used as a pretext for social spending cuts (Pentaraki, 2013c, 2019b, 2019c). However, we need to remember that social spending cuts are a result of the concentration of wealth in the hands of few (Gneiting et al., 2020) and as such demand the restructuring of society to meet the needs of all with well-funded services. Survivors of domestic violence need well-funded services, their lives depend on it (Weil, 2020).

\section{Conclusion}

The present paper has through a systematic literature search identified emerging issues in the area of DV linked to COVID-19 which are of relevance to many countries. These issues should be considered in order to respond to DV not only during the COVID-19 pandemic but also in future pandemics. Extreme events highlight issues surrounding DV about which the social work profession as well as other professions needs to be informed and continue to explore.

\section{Conflicts of Interest}

The authors declare no conflicts of interest regarding the publication of this paper.

\section{References}

Adams-Prassl, A., Boneva, T., \& Rauh, C. (2020). Inequality in the Impact of the Coronavirus Shock: Evidence from Real Time Surveys. Journal of Public Economics 189, Article ID: 104245. https://doi.org/10.1016/j.jpubeco.2020.104245

Ali, T. S., Asad, N., Mogren, I., \& Krantz, G. (2011). Intimate Partner Violence in Urban Pakistan: Prevalence, Frequency, and Risk Factors. International Journal of Women's 
Health, 3, 105-115. https://doi.org/10.2147/IJWH.S17016

Allen, M. (2014). Social Work and Intimate Partner Violence. London: Routledge. https://doi.org/10.4324/9780203387665

Ariyabandu, M. M., \& Wickramasinghe, M. (2003). Gender Dimensions in Disaster Management-A Guide for South Asia. Colombo: ITDG South Asia.

https://doi.org/10.3362/9781780445465

Bermudez, L. G., Stark, L., Bennouna, C., Jensen, C., Potts, A., Kaloga, I. F. et al. (2019). Converging Drivers of Interpersonal Violence: Findings from a Qualitative Study in Post-Hurricane Haiti. Child Abuse and Neglect, 89, 178-191.

https://doi.org/10.1016/j.chiabu.2019.01.003

Blaikie, P., Cannon, T., Davis, I., \& Wisner, B. (1994). At Risk: Natural Hazards, People's Vulnerability and Disasters. London: Routledge.

Boserup, B., McKenney, M., \& Elkbuli, A. (2020). Alarming Trends in US Domestic Violence during the COVID-19 Pandemic. The American Journal of Emergency Medicine. https://doi.org/10.1016/j.ajem.2020.04.077

Bradbury-Jones, C., \& Isham, L. (2020). The Pandemic Paradox: The Consequences of COVID-19 on Domestic Violence. Journal of Clinical Nursing, 29, 2047-2049. https://doi.org/10.1111/jocn.15296

Bradley, N. L., DiPasquale, A. M., Dillabough, K., \& Schneider, P. S. (2020). Health Care Practitioners' Responsibility to Address Intimate Partner Violence Related to the COVID-19 Pandemic. Canadian Medical Association Journal, 192, E609-E610. https://doi.org/10.1503/cmaj.200634

Campbell, A. M. (2020). An Increasing Risk of Family Violence during the Covid-19 Pandemic: Strengthening Community Collaborations to Save Lives. Forensic Science International: Reports, 2, Article ID: 100089. https://doi.org/10.1016/j.fsir.2020.100089

Canadian Women's Foundation (2020). Signal for Help.

https://canadianwomen.org/signal-for-help/

Castañeda Camey, I., Sabater, L., Owren, C., Boyer, A. E., \& Wen, J. (2020). Gender-Based Violence and Environment Linkages: The Violence of Inequality. International Union for Conservation of Nature (IUCN) Global Programme on Governance and Rights (GPGR), Gland, Switzerland: IUCN.

https://doi.org/10.2305/IUCN.CH.2020.03.en

Council of Europe (2011). Council of Europe Convention on Preventing and Combating Violence against Women and Domestic Violence CETS, No. 210. Istanbul: Council of Europe.

Dalton, S. (2020). When Staying at Home Can Mean Danger. Concept, 11, 1-3. http://concept.lib.ed.ac.uk/article/view/4371

Danis, F. S. (2003). Social Work Response to Domestic Violence: Encouraging News from a New Look. Affilia, 18, 177-191. https://doi.org/10.1177/0886109903018002007

Diemer, K., Humphreys, C., \& Crinall, K. (2017). Safe at Home? Housing Decisions for Women Leaving Family Violence. Australian Journal of Social Issues, 52, 32-47. https://doi.org/10.1002/ajs4.5

Dyer, H., Stelly, D., \& Watson, G. L. (2020). Intimate Partner Violence: Using Standardized Patients to Improve Trauma-Informed Care in the Era of the Covid-19 Pandemic. MedEdPublish. https://doi.org/10.15694/mep.2020.000079.1

Fisher, S. (2010). Violence against Women and Natural Disasters: Findings from Post-Tsunami Sri Lanka. Violence against Women, 16, 902-918. 


\section{https://doi.org/10.1177/1077801210377649}

Fogel, C. I., \& Woods, N. F. (Eds.) (2008). Women's Health Care in Advanced Practice Nursing. New York: Springer Publishing Company.

Garcia-Moreno, C., Jansen, H. A., Ellsberg, M., Heise, L., \& Watts, C. H. (2006). Prevalence of Intimate Partner Violence: Findings from the WHO Multi-Country Study on Women's Health and Domestic Violence. The Lancet, 368, 1260-1269. https://doi.org/10.1016/S0140-6736(06)69523-8

Gearhart, S., Perez-Patron, M., Hammond, T. A., Goldberg, D. W., Klein, A., \& Horney, J. A. (2018). The Impact of Natural Disasters on Domestic Violence: An Analysis of Reports of Simple Assault in Florida (1999-2007). Violence and Gender, 5, 87-92. https://doi.org/10.1089/vio.2017.0077

Gneiting, U., Lusiani, N., \& Tamir, I. (2020). Power, Profits and the Pandemic: From Corporate Extraction for the Few to an Economy that Works for All. https://oxfamilibrary.openrepository.com/handle/10546/621044

Graham-Harrison, E., Giuggrida, A., Smith, H., \& Ford, L. (2020). Lockdowns around the World Bring Rise in Domestic Violence.

https://www.theguardian.com/society/2020/mar/28/lockdowns-world-rise-domestic-vi olence

Higgins, N. (2020). Coronavirus: When Home Gets Violent Under Lockdown in Europe. https://www.bbc.co.uk/news/world-europe-52216966/

Hingorani, S. (2020). Isolated with Your Abuser? Why Family Violence Seems to Be on the Rise during COVID-19 Outbreak. Channel News Asia.

https://www.channelnewsasia.com/news/commentary/coronavirus-covid-19-family-vi olence-abuse-women-self-isolation-12575026

Holt, S., Øverlien, C., \& Devaney, J. (Eds.) (2017) Responding to Domestic Violence: Emerging Challenges for Policy, Practice and Research in Europe. London: Jessica Kingsley Publishers.

Ingala Smith, K. (2020). Counting Dead Women. Coronavirus Doesn't Cause Men's Violence against Women.

https://kareningalasmith.com/2020/04/15/coronavirus-doesnt-cause-mens-violence-ag ainst-women/

Jakobsen, H. (2014). What's Gendered about Gender-Based Violence? An Empirically Grounded Theoretical Exploration from Tanzania. Gender and Society, 28, 537-561. https://doi.org/10.1177/0891243214532311

John, N., Casey, S., Carino, G., \& McGovern, T. (2020). Lessons Never Learned: Crisis and Gender-Based Violence. Developing World Bioethics, 20, 65-68. https://doi.org/10.1111/dewb.12261

Johnson, M. P. (2006). Conflict and Control: Gender Symmetry and Asymmetry in Domestic Violence. Violence against Women, 12, 1003-1018.

https://doi.org/10.1177/1077801206293328

Johnson, M. P., Leone, J. M., \& Xu, Y. (2014). Intimate Terrorism and Situational Couple Violence in General Surveys: Ex-Spouses Required. Violence against Women, 20, 186-207. https://doi.org/10.1177/1077801214521324

Joska, J. A., Andersen, L., Rabie, S., Marais, A., Ndwandwa, E. S., Wilson, P. et al. (2020). COVID-19: Increased Risk to the Mental Health and Safety of Women Living with HIV in South Africa. AIDS \& Behavior, 24, 2751-2753.

https://doi.org/10.1007/s10461-020-02897-z

Kumar, N. (2020). Domestic Abuse: Women in Herat May Survive Coronavirus but Not 
Lockdown.

https://www.theguardian.com/global-development/2020/apr/21/domestic-abu se-women-in-herat-afghanistan-may-survive-coronavirus-but-not-lockdown

Marques, E. S., Moraes, C. L. D., Hasselmann, M. H., Deslandes, S. F., \& Reichenheim, M. E. (2020). Violence against Women, Children, and Adolescents during the COVID-19 Pandemic: Overview, Contributing Factors, and Mitigating Measures. Cadernos de Saude Pública, 36, e00074420. https://doi.org/10.1590/0102-311x00074420

Mazza, M., Marano, G., Lai, C., Janiri, L., \& Sani, G. (2020). Danger in Danger: Interpersonal Violence During COVID-19 Quarantine. Psychiatry Research, 289, Article ID: 113046. https://doi.org/10.1016/j.psychres.2020.113046

Moher, D., Liberati, A., Tetzlaff, J., Altman, D. G., \& The PRISMA Group (2009). Preferred Reporting Items for Systematic Reviews and Meta-Analyses: The PRISMA Statement. PLoS Medicine, 6, e1000097. https://doi.org/10.1371/journal.pmed.1000097

National Network to End Domestic Violence (NNEDV) (2019). The Safety Net Project. https://www.techsafety.org/resources

Nevo, I., \& Slonim-Nevo, V. (2011). The Myth of Evidence-Based Practice: Towards Evidence-Informed Practice. British Journal of Social Work, 41, 1176-1197. https://doi.org/10.1093/bjsw/bcq149

Nicolson, P. (2019). Domestic Violence and Psychology: Critical Perspectives on Intimate Partner Violence and Abuse. London \& New York: Routledge. https://doi.org/10.4324/9781351202077

O'Hara, M. (2015). Austerity Bites: A Journey to the Sharp End of Cuts in the UK. Bristol: Policy Press. https://doi.org/10.2307/j.ctt13x0q6t

Parkinson, D., \& Zara, C. (2013). The Hidden Disaster: Domestic Violence in the Aftermath of Natural Disaster. Australian Journal of Emergency Management, 28, 28-35.

Pawson, R., Boaz, A., Grayson, L., Long, A., \& Barnes, C. (2003). Types and Quality of Social Care Knowledge. Stage Two: Towards the Quality Assessment of Social Care Knowledge. ESRC UK Centre for Evidence Based Policy and Practice: Working Paper 18.

Pence, E., \& Paymar, M. (1993). The Duluth Model. New York: Springer.

Pentaraki, M. (2009). Family Violence Agencies in Greece and Community Development Proposals to Address the Issue of Violence against Women. In K. Samaratzi, \& N. Papachristopoulos (Eds.), Family and New Forms of Partnership (pp. 209-228). Athens: Opportuna. (In Greek)

Pentaraki, M. (2013a). Measures to Fight Violence Against Women. Spain: European Commission's Exchange of Good Practises Programme.

Pentaraki, M. (2013b). The Class Impact of Post Disaster Restoration Policies: The Example of Ilia, Greece and the Need for a Politics of Disaster. International Social Work, 56, 761-774. https://doi.org/10.1177/0020872812440717

Pentaraki, M. (2013c). "If We Do Not Cut Social Spending, We Will End up Like Greece": Challenging Consent to Austerity through Social Work Action. Critical Social Policy, 33, 700-711. https://doi.org/10.1177/0261018313489941

Pentaraki, M. (2017). The Fear of Double Disclosure and Other Barriers to Help Seeking. In S. Holt, C. Øverlien, \& J. Devaney (Eds.), Responding to Domestic Violence: Emerging Challenges for Policy, Practice and Research in Europe (pp. 135-151). London: Jessica Kingsley Publishers.

Pentaraki, M. (2019a). Considerations When Using Online/Distant Technology for Ser- 
vice Provision in the Field of Domestic and Sexual Violence. In Erasmus + KA2 Cooperation for Innovation and the Exchange of Good Practices Agreement Number: 2017-1-EL01-KA202-036170. Belfast: Queen's University.

Pentaraki, M. (2019b). Austerity Common Sense and Contested Understandings of the Austerity Measures within a Leadership of a Professional Association of Social Workers. European Journal of Social Work, 22, 935-946. https://doi.org/10.1080/13691457.2018.1435507

Pentaraki, M. (2019c). Practicing Social Work in a Context of Austerity: Experiences of Public Sector Social Workers in Greece. European Journal of Social Work, 22, 376-387. https://doi.org/10.1080/13691457.2017.1369396

Pentaraki, M., \& Speake, J. (under review) Technology-Facilitated Abuse within the Context of Intimate Partner Violence: Barriers to and Recommendations for Safety Planning.

Peterman, A., Potts, A., O’Donnell, M., Thompson, K., Shah, N., Oertelt-Prigione, S. et al. (2020). Pandemics and Violence Against Women and Children. Centre for Global Development Working Paper 528, Washington DC: Center for Global Development. https://www.cgdev.org/sites/default/files/pandemics-and-vawg-april2.pdf

Ragavan, M. I., Culyba, A. J., Muhammad, F. L., \& Miller, E. (2020). Supporting Adolescents and Young Adults Exposed to or Experiencing Violence during the COVID-19 Pandemic. Journal of Adolescent Health, 67, 18-20.

https://doi.org/10.1016/j.jadohealth.2020.04.011

Rajan, D., Koch, K., Rohrer, K., Bajnoczki, C., Socha, A., Voss, M. et al. (2020). Governance of the Covid-19 Response: A Call for More Inclusive and Transparent Decision-Making. British Medical Journal Global Health, 5, e002655.

https://doi.org/10.1136/bmigh-2020-002655

Refuge (2020). 25\% Increase in Calls to National Domestic Abuse Helpline Since Lockdown Measures Began. London: Refuge. (Press release 6 April)

Schumacher, J. A., Coffey, S. F., Norris, F. H., Tracy, M., Clements, K., \& Galea, S. (2010). Intimate Partner Violence and Hurricane Katrina: Predictors and Associated Mental Health Outcomes. Violence and Victims, 25, 588-603.

http://www.ncbi.nlm.nih.gov/pmc/articles/PMC3394178/pdf/nihms383057.pdf https://doi.org/10.1891/0886-6708.25.5.588

Slakoff, D. C., Aujla, W., \& PenzeyMoog, E. (2020). The Role of Service Providers, Technology, and Mass Media When Home Isn't Safe for Intimate Partner Violence Victims: Best Practices and Recommendations in the Era of CoViD-19 and Beyond. Archives of Sexual Behavior, 1-10. https://doi.org/10.1007/s10508-020-01820-w

Smith, J. (2019). Overcoming the "Tyranny of the Urgent": Integrating Gender into Disease Outbreak Preparedness and Response. Gender and Development, 27, 355-369. https://doi.org/10.1080/13552074.2019.1615288

Stark, E. (2007). Coercive Control: How Men Entrap Women in Personal Life. New York: Oxford University Press.

Taub, A. (2020). A New Covid-19 Crisis: Domestic Abuse Rises Worldwide. New York Times, 4 May 2020.

https://www.nytimes.com/2020/04/06/world/coronavirus-domestic-violence.html

True, J. (2012). The Political Economy of Violence against Women. New York: Oxford University Press. https://doi.org/10.1093/acprof:oso/9780199755929.001.0001

UK Parliament (2020). Home Office Preparedness for Covid-19 (Coronavirus): Domestic Abuse and Risks of Harm within the Home. A Report by MPs, London: UK Parlia- 
ment.

https://publications.parliament.uk/pa/cm5801/cmselect/cmhaff/321/32105.htm

United Nations (UN) (2015). The World's Women 2015: Trends and Statistics. United Nations Department of Economic and Social Affairs, Statistics Division 2015, New York: United Nations. https://unstats.un.org/unsd/gender/worldswomen.html

United Nations Population Fund (UNFPA) (2020). Impact of the COVID-19 Pandemic on Family Planning and Ending Gender-Based Violence, Female Genital Mutilation and Child Marriage. Interim Technical Note Information as of 27 April 2020. New York: United Nations Population Fund.

United Nations Women (UN Women) (2020a). COVID 19 and Ending Violence against Women and Girls. New York: United Nations Women.

United Nations Women (UN Women) (2020b). Women's Rights in Review: 25 Years After Beijing. New York: United Nations Women.

Usher, K., Bhullar, N., Durkin, J., Gyamfi, N., \& Jackson, D. (2020). Family Violence and COVID-19: Increased Vulnerability and Reduced Options for Support. International Journal of Mental Health Nursing, 29, 549-552. https://doi.org/10.1111/inm.12735

Van Gelder, N., Peterman, A., Potts, A., O’Donnell, M., Thompson, K., Shah, N., \& Oertelt-Prigione, S. (2020). COVID-19: Reducing the Risk of Infection Might Increase the Risk of Intimate Partner Violence. EClinicalMedicine, 21, Article ID: 100348. https://doi.org/10.1016/j.eclinm.2020.100348

Vieira, P. R., Garcia, L. P., \& Maciel, E. L. N. (2020). Isolamento Social e o Aumento da ViolênciaDoméstica: O Que Isso Nos Revela? Revista Brasileira de Epidemiologia, 23, e200033. https://doi.org/10.1590/1980-549720200033

Weil, S. (2020). Two Global Pandemics: Femicide and COVID-19. Trauma and Memory, $8,110-112$.

Weiner, J. (2020). COVID-19 and Domestic Violence in South Africa. Oxford Human Rights Hub Blog.

http://ohrh.law.ox.ac.uk/covid-19-and-domestic-violence-in-south-africa/

Williamson, E. (2000). Domestic Violence and Health: The Response of the Medical Profession. Bristol: Policy Press. https://doi.org/10.2307/j.ctt1t896sh

Women's Aid (2020). Covid-19/Coronavirus: Safety Advice for Survivors. https://www.womensaid.org.uk/covid-19-coronavirus-safety-advice-for-survivors/

Woodlock, D., McKenzie, M., Western, D., \& Harris, B. (2020). Technology as a Weapon in Domestic Violence: Responding to Digital Coercive Control. Australian Social Work, 73, 368-380. https://doi.org/10.1080/0312407X.2019.1607510

World Health Organization (WHO) (2013). Global and Regional Estimates of Violence against Women: Prevalence and Health Effects of Intimate Partner Violence and NonPartner Sexual Violence. Geneva: World Health Organization.

World Health Organization (WHO) (2020a). Coronavirus Disease (COVID-19). Situation Report 124.

https://www.who.int/docs/default-source/coronaviruse/situation-reports/20200523-cov id-19-sitrep-124.pdf?sfvrsn=9626d639 2

World Health Organization (WHO) (2020b). COVID-19 and Violence against Women What the Health Sector/System Can Do. Geneva: World Health Organization.

Zhang, W. Q. (2020). Domestic Violence Cases Surge during COVID-19 Epidemic. March 2020.

https://www.sixthtone.com/news/1005253/domestic-violence-cases-surge-during-covid 
-19-epidemic

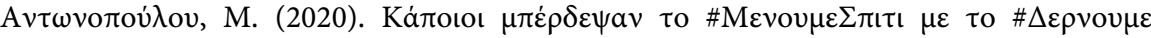

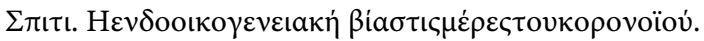

https://www.ladylike.gr/opinions/kapoioi-berdepsan-to-menoumespiti-me-to-dernou me-spiti-i-endooikogeneiaki-via-stis-meres-tou-koronoiou/ 